\title{
Angry Anglos and Aspirational Asians: Everyday multiculturalism in the selective school system in Sydney
}

\section{Christina Ho}

Faculty of Arts and Social Sciences, University of Technology Sydney, Australia

Christina Ho

Faculty of Arts and Social Sciences

University of Technology Sydney

PO Box 123

Broadway NSW 2007

Tel: +61-2-9514 1946

Email: christina.ho@uts.edu.au

Christina Ho is a Senior Lecturer in the Faculty of Arts and Social Sciences at the University of Technology Sydney. She researches migration and multiculturalism in Australia, focusing currently on cultural diversity and education. Her books include 'For those who've come across the seas': Australian Multicultural Theory, Policy and Practice; Beyond the Hijab Debates: New Conversations on Gender, Race and Religion; and Migration and Gender Identity: Chinese Women's Experiences of Work, Family and Identity in Contemporary Australia. 


\title{
Angry Anglos and Aspirational Asians: Everyday multiculturalism in the selective school system in Sydney
}

\begin{abstract}
'Asian whiz kids' perfect test scores'. 'Selective schools and tiger parents'. These types of headlines highlight the increased visibility of academically successful students from Asian migrant backgrounds, in Australia and other western countries. They also point to anxiety about the perceived aggressive 'tiger' parenting often associated with Asian academic success. This paper focuses on the forms of everyday multiculturalism found in and around high performing selective schools and classes in Sydney, Australia, almost all of which are dominated by Asian-Australian students. Drawing on interviews with parents and students from Anglo- and Asian-Australian backgrounds, it documents the different positionalities adopted by participants within these culturally diverse settings, including anger, aspiration and cosmopolitanism. This potentially volatile combination of approaches to diversity reveals some of the social consequences of neoliberal migration and education policies.
\end{abstract}

Keywords: everyday multiculturalism, ethnicity, education, selective schools, racism, racialisation, migration, school choice

\section{Introduction}

Like many other migrant destination countries, Australia's neoliberal migration policy has led to a dramatic growth in well-educated professionals from Asia arriving as skilled and business migrants over the last 20 years. Often their motivation for migration is their children's education. Over the same period, Australian education policy, following global trends, has also become more neoliberal in orientation, with a greater emphasis on school choice and competition, and disproportionately high levels of government funding for private schools.

These two policies have helped create some unusual social environments: in Sydney and elsewhere, elite academically-selective public schools and classes have become dominated by Asian-Australian students. These children of Asian migrants come from families that deeply value education as the primary mechanism for social mobility, 
particularly in a new society where they lack the social and cultural capital possessed by their local counterparts. Arriving during an era of intensified educational competition, they typically adopt highly instrumental approaches to education, particularly around school choice (and residential choice), private tutoring, close monitoring of children's time use, and targeted training for selective admissions tests (Watkins \& Noble, 2013; Sriprakash et al, 2015). These approaches mirror those of Asian migrants in other Anglophone countries (Archer \& Francis, 2007; Louie, 2004; Lee \& Zhou, 2015).

As in other Anglophone countries, these approaches cause anxiety and resentment among many in the majority White population, who feel increasingly excluded from the elite educational programs now dominated by migrant children (Broinowski, 2015; Ho, 2017a). Although White middle-class families have often adopted similar instrumental approaches to their children's education (Lareau, 2003; Reay, 2004; Vincent and Ball, 2007) - but without the reliance on commercial tutoring centres - they see Asian 'tiger parenting' as a new threat to the self-perceived tradition of 'relaxed' Western parenting. Some families now shun selective schools as 'too Asian' (Milburn, 2011; Ho, 2015). Anglo-Australians who secure entry find themselves in the unfamiliar position of being an ethnic minority within the school community.

While the politics of Asian domination of selective schools have been regularly debated in the mainstream media in Australia (e.g. Patty, 2010; Milburn, 2011; Broinowski, 2015; Neill, 2016), there has been little scholarly attention on this dramatic transformation within the Australian education system, and work focusing on ethnicity and selective schools has often focused on media representations (e.g. Ho, 2017a; Proctor and Sriprakash, 2017), rather than the lived experiences of those within these communities (Watkins, 2017 is an exception).

This paper addresses the gap in our understanding of the changing demography of elite public schools, and foregrounds the experiences of families within these communities. In particular, it examines social relations within school communities using the framework of 'everyday multiculturalism'. Schools have been theorised as a significant site for everyday multiculturalism, because of the daily, routinised interaction of students, families and staff that occurs within and around school communities (Amin, 2002; Neal \& Vincent, 2013; Noble, 2009; Ho et al, 2015).

This paper is based on in-depth, semi-structured interviews with 20 students and parents (11 parents and 9 students) who had direct experience of selective schools and classes in Sydney. Fourteen respondents were or had children attending at the time of interview; the 
remainder were students who had recently graduated. Respondents were recruited via online invitations (e.g. via Facebook groups) and through snowball recruiting. Online invitations attracted mostly Anglo-Australian respondents, requiring more targeted recruitment of AsianAustralians through snowballing via personal and professional networks. Online recruitment may have over-sampled respondents with strong opinions on the topic, and in particular, Anglo-Australians angry with what they perceive to be unjust outcomes in the current selective school system. On the other hand, the inclusion of the researcher's obviously Asian name in the publicity may have mitigated this to some extent. While my respondents were geographically spread across metropolitan Sydney, a sizeable minority resided on Sydney's wealthy North Shore, where there is a concentration of selective schools and classes. Respondents were evenly split between Anglo- and Asian-Australians. While my AsianAustralian respondents had migrated from various countries, including China, Hong Kong, Malaysia and Vietnam, I refer to them collectively as Asian-Australian, primarily because that is how they categorised themselves.

\section{Selective schools and classes: Background}

Following the global education reform movement emphasising school choice (Campbell et al, 2009; Windle, 2015), the Australian education system has become increasingly fragmented in the last 20 years, as schools seek to distinguish themselves to attract greater numbers of educational 'consumers'. This has created more marked hierarchies of desirability within the schooling system. The New South Wales (NSW) education system is particularly hierarchical compared to other jurisdictions in Australia, although other states are moving in a similar direction. While most children in NSW attend comprehensive public schools, the last 20 years has seen the growth of public academically-selective high schools, and at the primary level, Opportunity Classes (OCs) running an accelerated curriculum for high achieving students in Years 5 and 6.

The number of selective schools and classes has grown dramatically in the last two decades, and there are now 47 fully or partially selective schools in NSW (NSW Government, 2016a), mostly concentrated in Sydney. At the primary level there are 75 schools with Opportunity Classes (NSW Government, 2016b). In addition, some primary and secondary schools operate Gifted and Talented Programs, another attempt at differentiation within an increasingly competitive school 'market'. 
Correspondingly, the local comprehensive public school has become less and less desirable, not least because federal government funding has disproportionately favoured private schools over public schools (Forsey, 2010; Windle, 2015), which, coupled with the fees paid by parents, has resulted in an ever-widening resource gap between public and private schools. In this environment, selective schools and those offering OCs and Gifted and Talented streams become a beacon of 'quality' in the public system, while draining comprehensive public schools of some of their best talent. This is in addition to the exodus of middle-class families to private schools (Campbell et al, 2009).

Selective high schools in NSW routinely dominate the annual league tables of Higher School Certificate (HSC) results. For example, James Ruse Agricultural High School, in north-west Sydney, has topped the league table every year for the last 20 years (Armitage, 2016). It is closely followed by other selective schools such as Sydney Girls and Boys, and North Sydney Girls and Boys. These public schools typically outperform elite private schools. Admission is controlled via a notoriously difficult test, and entry is extremely competitive. In 2016, two thirds of applicants failed to gain a place in a selective high school (Armitage, 2016).

Apart from their academic achievements, one other feature has been increasingly remarked upon in public debates: selective schools are heavily dominated by AsianAustralian students. In the majority of selective schools in Sydney, students from language backgrounds other than English (LBOTE) comprise at least 80 per cent of overall enrolments (ACARA, 2016), and the majority of these students are from Asian backgrounds. The table below shows the figures for ten of Sydney's top-performing selective schools (as measured by HSC rankings). Once the preserve of gifted Anglo-Australian students, in the last 20 years, NSW selective schools have become increasingly dominated by children of migrants from China, Korea, other East and South-east Asian nations, and increasingly, India and South Asia.

The table also provides a profile of levels of advantage within each school, showing the percentage of families within the top quarter of socio-educational advantage. Socioeducational advantage ratings consider parents' education and occupation, factors known to have a significant impact on students' educational outcomes (ACARA, 2017). The concentrated advantage found in selective schools is striking, and mirrors the profile of many prestigious high-fee private schools in Sydney (Ho, 2017b). 
Top Selective schools in Sydney: Ethnicity and Socio-educational Advantage

\begin{tabular}{|l|l|l|}
\hline School & $\begin{array}{l}\text { \% from a Language } \\
\text { Background Other Than } \\
\text { English }\end{array}$ & $\begin{array}{l}\text { \% from top quarter, } \\
\text { Socio-Educational } \\
\text { Advantage }\end{array}$ \\
\hline $\begin{array}{l}\text { James Ruse Agricultural High } \\
\text { School }\end{array}$ & 97 & 89 \\
\hline Baulkham Hills High School & 94 & 78 \\
\hline $\begin{array}{l}\text { North Sydney Boys High } \\
\text { School }\end{array}$ & 92 & 78 \\
\hline $\begin{array}{l}\text { North Sydney Girls High } \\
\text { School }\end{array}$ & 93 & 79 \\
\hline Hornsby Girls High School & 87 & 84 \\
\hline Sydney Boys High School & 89 & 74 \\
\hline $\begin{array}{l}\text { Northern Beaches Secondary } \\
\text { College Manly }\end{array}$ & 42 & 87 \\
\hline Conservatorium High School & 71 & 80 \\
\hline $\begin{array}{l}\text { Normanhurst Boys High } \\
\text { School }\end{array}$ & 87 & 73 \\
\hline Sydney Girls High School & 87 & 81 \\
\hline Source: ACARA, 2016 & & 80 \\
\hline
\end{tabular}

Source: ACARA, 2016

The makeup of these schools is a direct reflection of Australia's elitist migration policy, which admits applicants on the basis of their professional skills, qualifications and wealth. Such policies have attracted large numbers of skilled migrants from Asia. In 2009, China became the largest source of migrants to Australia, eclipsing the UK and New Zealand (Martin, 2009). And in 2013, Indian migrants outnumbered Chinese migrants, comprising nearly 20 per cent of all permanent settlers (SBS, 2015). Migrants from Asia tend to be highly educated. Among Australia's China-born and South Korea-born populations, nearly 40 per cent hold a university degree, approximately double the national average (DIAC, 2014a $\& 2014 b$ ). Among the India-born population, the figure is over 50 per cent (DIAC, 2014c). Not only are these migrants more highly educated than the national average, but they are also more educated than their non-migrant counterparts in their country of origin. For example, only 4 per cent of adults in China have a degree (Lee and Zhou, 2017), meaning that Chinese 
migrants in Australia are approximately ten times more likely to be university educated than their non-migrant counterparts in China. Lee and Zhou (2015) characterise this double positive selectivity as 'hyper-selectivity'.

Therefore, it is not surprising that these migrants pay a great deal of attention to their children's education. They value education because of the role it has played in their own lives, not least enabling them to migrate to an advanced Western nation. In addition, as migrants from non-English speaking backgrounds, they typically experience downward mobility and often discrimination in the labour market (Booth et al, 2012), creating an 'immigrant pessimism' (Louie, 2004) that causes them to take a 'credentialist' approach (Aris, 2017) to schooling. In their typology of the Australian middle classes, Campbell et al (2009, p. 33) categorise many recent migrants as members of the 'marginal middle class' who hope to achieve middle-class status for their children through education, and selective schools, as high-achieving public schools with minimal fees, present the obvious target for their aspirations.

These factors partly explain Asian-Australians' dominance of selective schools and classes. This phenomenon marks a dramatic shift in the relations of privilege in the Australian education landscape. As Campbell et al (2009, p. 107) state, the new middle class that benefited most from selective schools is 'being displaced by an even newer new middle class, with an equally strong but different ethnic character'. The next section examines ethnicity more closely, within the framework of 'everyday multiculturalism'.

\section{Everyday multiculturalism and schools}

Part of the 'convivial turn' (Neal \& Vincent, 2013) that seeks to focus on everyday encounters in diverse communities, 'everyday multiculturalism' is a growing field of research that advocates studying ordinary interactions as an important part of understanding intercultural relations. Scholars of everyday multiculturalism demonstrate how encounters across cultural difference in local settings enable individuals to develop acceptance of others. Cultural difference becomes normalised and unremarkable, so that people deal with each other as individuals rather than as members of an ethnic group - everyday multiculturalism 'dissolves' unfamiliarity (Noble, 2009, p. 61).

Schools have been an important focus of everyday multiculturalism. They are part of the 'institutions of everyday life' (Harris, 2013, p. 45), and moreover, ones that obligate daily 
participation by almost all children and young people, and their families, in every community, in every modern society. Local comprehensive public schools are especially significant because students and families daily encounter the full range of community diversity within the school. Amin (2002) sees schools as 'micropublics', places where people are thrown together and required to engage with each other and work together in a common activity, in the process enabling 'unnoticeable cultural questioning or transgression'. Neal and Vincent (2013) describe schools - and surrounding homes, streets, parks and shops - as 'convergent places', spaces of 'routine encounters of difference' where students and parents from different backgrounds need to negotiate relationships on a regular basis over many years. Noble (2009, p. 52) sees schools as sites of intermingling, 'where streams of people parents, grandparents, older siblings and other carers - converge and diverge', and where cultural differences 'interweave themselves'. In the process, cross-cultural understanding and friendships can develop, or at the very least, a recognition of the right of others to inhabit a shared school community (Ho, 2011). Meanwhile, Poyatos Matas and Bridges $(2008,2009)$ argue that schools are crucial for 'preparing global citizens' and that schools with high levels of 'multicultural capital' - which includes the skills and background of staff and students have the greatest capacity to engage in transformative approaches. In these schools, diversity is integrated into everyday teaching and learning, rather than 'celebrating multiculturalism through one off cultural days and festivals' (Poyatos Matas and Bridges, 2009, p. 390).

In contrast to these positive assessments, other scholars have emphasised the limits of cross-cultural encounters, even within culturally diverse school communities. Hollingworth and Mansaray (2012) argue that schools are 'sites of differentiation', and relationships within them both reflect and reproduce existing social hierarchies and inequalities. Reay et al (2007) argue that white privilege shapes encounters within diverse schools, such that white middleclass families 'extract value' from their multi-ethnic other. Similarly, Ho et al (2015) show that even among parents professing to value diversity, a 'cosmo-multiculturalism' is common, whereby diversity is a commodity to be consumed (e.g. learning a foreign language) rather than an everyday lived experience with cultural others.

Building on this work, this paper shows that the structure of selective schools in Sydney creates an unusual form of everyday multiculturalism. The paper shows that not only are these schools segregated from their local communities, but within the schools, students and families often self-segregate, and the overall environment is hyper-racialised. The following sections describe experiences of Anglo and Asian-Australians within these communities. 


\section{Angry Anglos: 'Selective schools have become hothouses'}

'I feel a sense of loss for my high school years. I feel I didn't get the high school [experience] that people are meant to get' (Blaise, Anglo-Australian student).

One of the most surprising findings in this study was the depth of anger and resentment felt by many Anglo-Australians in relation to the selective school system, particularly among parents. This section describes the resentment of parents angry at what they perceived to be a 'gaming' of the system by Asian-Australian families, and details the social segregation within selective school communities.

The dominance of Asian-Australian students in selective schools and classes was a cause of concern for many of my Anglo-Australian parent respondents. The strongest anxieties related to the perception that Asian migrant parents were overly aggressive and competitive, and 'pushed' their children into excessive study. Hostility towards the use of private tutoring or coaching - a practice commonly associated with Asian migrants (Sriprakash et al, 2015) - was emblematic of these concerns. Anglo-Australian parents stated that the prevalence of tutoring meant that 'genuinely gifted' students now had no chance of entry into a selective school. They argued that although these schools were designed for naturally gifted students, who would be unchallenged or bullied at comprehensive schools, they were now transformed into academic 'hothouses' catering for those who relied on tutoring and 'cramming', rather than talent. As Ros stated, 'You've got a lot of kids there who really don't have a good quality of life. I feel very sorry for them, the pressure they're under... I don't think it's right. To me that's child abuse...'

Anglo-Australian parents tended not to use private tutoring, some being adamant in their opposition to the practice, and emphasising their children's lack of preparation for selective admissions tests. As Tricia explained:

So our philosophy has been that if they're going to get into any type of program, they have to do it on their own merits. I didn't want them in a situation where they were coached to get in the program and then had to be coached up. So we did no preparation for the gifted and talented test.

Or in the words of Gill, who had three children in a selective school: 'We were very aware that we wanted them to get in on their ability as opposed to having to swot for it'. 
The use of tutoring among Asian-Australians was leading to resentment among many Anglo-Australian families whose children had missed out on a selective place. Two of my respondents described how 'local' children were being excluded from selective classes in favour of Asian migrant children from out of the area. This was most stark in primary schools that operated Opportunity Classes or gifted and talented programs where admission was via a test, enabling children from outside of the school to gain entry into these prestigious programs during the senior years of primary school. Parents were particularly hostile where the majority of selective classes comprised externally-sourced students, while the majority of internal students had missed out on a place. For example, Liz stated, discussing the gifted and talented program in her children's primary school:

There are lots of Jewish kids in the school. So many that there are after-school Hebrew classes. But there is not a single Jewish child in my kids' [gifted and talented] classes. So you wonder, how can there not be any gifted Jewish kids? Those parents are angry. They've lived there for ten years, they're part of the school community, and they're cut out of it.

As Tricia stated:

More kids are coached for longer and there's almost this contagion that grips the parents around - we have to make sure our kids get in. So much so that a friend of mine... she's not coached her kids or anything like that... her daughter didn't get into the program for this and she was distraught, completely distraught...

There was a general perception among my Anglo-Australian parent respondents that Asian migrant parents took an excessively instrumental approach to schooling, which reduced education to excelling in exams. This was at the cost of a more holistic experience, including participating in the life of the school community. Ros' comment was typical: 'Everything that's done at the school, I would say 90 per cent of the helpers at school are non-Asian, even though they have few numbers. It's really frustrating.' According to Ros, the Asian parents rarely attended school social events, nor did they support fundraising efforts.

And even when Asian-Australian children undertook extra-curricular activities, their parents took an excessively competitive and instrumental approach, even in primary school, according to Liz:

Both my kids play string instruments. The Asian kids whip them. They practice an hour a day... It's not just music. Every super star child at the swimming carnival is Asian. They're doing hours a day, going up and down the pool, perfecting. Anything that has a technique involved, that you can perfect, like swimming, violin, that's where they're going, and doing at a high level. But it's a limited range of activities. 
Another Anglo-Australian parent, Suzie, declined an offer from an elite selective school for her son, stating: 'We just were concerned that would our child feel a sense of belonging if he's with a lot of kids who are spending every day studying...' Or in the words of Liz: 'Most Caucasian parents would not dream of sending their kids to North Sydney Girls or North Sydney Boys, because they'd be a minority.'

Anglo-Australians being a 'minority' was a strong theme in my interviews with the students. Almost every student interviewee spoke about Anglo-Australian students selfsegregating at school, forming their own friendship groups, separate from the Asian majority. Students' self-segregation in school has attracted some comment in studies of ethnicity and youth, and although it is sometimes a sign of racist hostility, for example, in the US (Thomas, 2011), in the Australian context, it has been more commonly explained as a natural clustering of individuals who feel that their shared ethnicity will enable better relationships of understanding and friendship (Willoughby, 2007). However, there is no hostility toward ethnic others, and friendship groups can be porous and transitory, dependent on factors such as taste, activities, language capacities and personality (Harris, 2013, p. 54). And the lack of interaction is not seen as problematic because, as Harris (2013, p. 54) argues, sharing space productively sometimes means living 'side by side' rather than 'face to face'. Moreover, even one's own ethnic identity is not necessarily stable; young people 'work the hyphens' (Fine, cited in Harris, 2013, p. 4) of their own identities and ideologies, and engage in contextspecific 'strategic essentialism' and 'strategic hybridity' (Noble et al, 1999).

However, some of my Anglo-Australian student respondents said that they felt their minority status keenly, and it was the cause of social isolation and disengagement. One respondent, Blaise, studying at university at the time of interview, reflected on her experience of a selective high school in Sydney: 'I felt very isolated being one of the only white girls, and I felt a lot of the Asian girls in the school were kind of standoffish towards me.' She discusses the self-segregation where 'the white girls' would sit at a particular table at lunchtime, isolating themselves from the other students: 'We'd do things like count the white girls in all of the school photos, in all of the different years, and track what the changes over time were. It became a way of dealing with the isolation.'

Although Blaise said that white students often felt excluded, she acknowledged that their isolation was also self-perpetuated. They dedicated a great deal of energy to 'differentiating ourselves', as people who 'thought differently', and who 'weren't coached'. She describes how the white students in her school even invented their own language: 
In reaction to when the Chinese girls would speak Canto or Mando around us, we created a language - we came up with a language. So we'd speak Alibi, and we'd speak that really loudly and obnoxiously whenever any girls were speaking Chinese around us. Because we were like, if you can lock us out of your world, we'll lock you out of ours.

Blaise's experience is mirrored in that of Robert, another Anglo-Australian student in a selective school, who I interviewed alongside his mother, Ros. Ros stated that Robert had 'very few friends' and was socially isolated at school. She said they had tried to develop friendships but,

Even when you arrange things they all just cancel at the last minute, they're not allowed out, they have to coach [i.e. attending private tutoring]. Robert's very sporty, so he does a lot of sport and the standard of sport is really poor... So I think he's really suffered by going to that school. I wouldn't do it again.

Indeed, although Robert's younger sister was accepted into a selective school, the family decided to send her to the local comprehensive school instead, primarily to ensure she had a better social experience.

Although both my Anglo and Asian-Australian student respondents emphasised that racism was rare within their schools, there was certainly a strong impression that ethnicity played a large role in how individuals identified themselves and others. For example, 'counting the white kids' in each grade (an activity mentioned by more than one student) indicates the centrality of ethnicity to the identification of others. Arguably, identifying with 'other white kids' in school photographs is not about a natural comfort with co-ethnics, but an abstract, essentialist assumption that your visible ethnicity defines who you are, in sharp distinction to visibly different ethnic others.

\section{Aspirational Asians: 'Getting ahead and staying on top'}

'Ifeel very Asian. I think Asians in general, ABCs [Australian-born Chinese], they either run towards identifying as Asian or they run away from that. I was one of the people who was just, 'hi I'm Asian, I'm really proud to be Asian' (Amy, Chinese-Australian student).

All of my Asian-Australian respondents were very conscious of the Asian domination of their schools. Often they expressed pride in the achievements of Asian-Australians, and comfort in inhabiting an Asian-dominated environment, in which a culture of hard work and 'migrant 
sacrifice' was widespread. However, their often essentialist approach to culture sometimes ignored the role played by structural factors in the production of this 'culture' of hard work. In this section, I analyse everyday multicultural relations in selective schools from the perspective of Asian-Australians, and explain how the migrant experience, as much as innate ethnic 'culture', is significant in shaping Asian-Australian aspirations and approach to education.

Before proceeding, the category of 'Asian' needs some discussion. The conflation of 'Chinese' with 'Asian' in Amy's comment above illustrates the social construction of the category of 'Asian' within the Australian context. As already noted, until recently, migrants from China outnumbered those from other Asian countries, and their dominance is reflected in selective school enrolments. However, given the internal diversity of 'the Chinese' in Australia, who come from many countries, speak different dialects and are sharply divided politically, even the category of 'Chinese' is homogenising. 'Asian' and 'Chinese' only gain meaning within the specific history of inter-cultural relations in the Australian context (for example, perhaps reflecting the majority population's inability or refusal to distinguish between different groups of 'Asians'), and within the more specific context of Australian youth culture and schools, where students deploy ethnic categories that disguise their internal diversity. However, such practices mirror those documented elsewhere, for example, Pollock's study of 'race-bending' in a California school, where 'despite the "mixed"-up roots and global routes' that were a feature of the school community, 'racial identification was an accepted process of social simplification' (2004, p. 35).

This 'strategic essentialism' (Spivak, 1987) can be seen as a way to boost one's power in an unequal environment (Omi and Winant, 1994). And at times it contributed to an 'us and them' mentality, with 'Asian pride' sometimes extending to resentment at the perceived privileges enjoyed by Anglo-Australian students. As Winnie said, 'There was a very, very, very, very strong distinction between the Caucasian and the Asian... Within the school community we kind of knew who the prefects were because they're all white.' AngloAustralian students were disproportionately represented among prefects and other school leaders, according to Winnie, who also claimed that Anglo students with influential parents could enlist them to gain special privileges, such as being transferred into more desirable classes. In comparison, as Lien, a Vietnamese-Australian parent commented, most of the parents of her children's friends at selective schools didn't speak English well. 'How would they even be able to talk to the teachers if there's a problem?' 
Others expressed a more subdued sense of comfort at being surrounded by other Asian-Australians, which meant there was familiarity and common ground, making it easy to form friendships (cf. Willoughby 2007). Amy said that it was 'comfortable' having all Asian friends; they could talk about 'our Asian struggles' with parents, 'Asian expectations', and 'struggling with ABC [Australian-born Chinese] identity'. Similarly, Wei said that she did not 'connect' with Anglo-Australians, despite trying to form friendships with them, and inevitably gravitated towards all-Asian friendship groups. Felicity said that although she initially wanted desperately to distinguish herself from the 'mass of Asians', and sought friendships with Anglo students, eventually, going to an Asian-dominated school enabled her to be comfortable with her Chinese ethnic background, for the first time in her life.

These students identified strongly with being 'Asian', and adopted culturally essentialist definitions of their identity, for example, equating 'Asianness' with rigour, hard work and competitiveness. Winnie described her tutoring centre, which was 'very strict and like very typical Asian kind of thing', for example, all the students' marks were displayed on the board and competitiveness was emphasised. Amy explained that while tutoring was traditionally used 'if you're struggling', now it's about 'getting ahead'. She explained this in cultural terms: 'I think it is kind of Asian, like in terms of being ahead, always knowing your competition'.

While these respondents' explanations of their behaviour revolved around 'culture', it is also possible to read their stories in terms of the migrant experience, rather than a purely 'Asian' one. Virtually all my Asian-Australian respondents conformed to the stereotype of the hard-working migrant determined to use education to enhance social mobility. Almost all the students had spent months or years in private tutoring in the lead up to selective admissions tests. All emphasised the importance of educational success, which was defined as a family pursuit rather than just the responsibility of the child. One of my ChineseAustralian respondents, Lily, recounted the approach of one family she knew. Not only did the daughter attend private tutoring three times a week, but in the lead up to the selective school test, no one in the family watched any television for a year: 'They did not turn on TV even one time for the whole year, in order to cooperate with their daughter's study'.

Many respondents, especially the students, emphasised the sacrifices their families had made to migrate to Australia, obligating children to work hard to ensure they achieved the career goals that were elusive to the first generation of migrants. For example, Winnie explained how her mother had come from a wealthy and influential family in Shanghai, where she had always excelled - 'she was already the top, like, one per cent' - whereas in 
Australia, she had given up her career to be a full-time mother. Similarly, Amy saw education as 'a big part of Asian culture', because Asian parents had migrated, so wanted 'the best for their kids'. In comparison, according to Amy, white parents just wanted their kids to 'enjoy life' and do 'what they want'.

Many of the Asian-Australian parents were acutely aware of the disadvantages they faced as migrants in Australia, including the ever-present threat of racial discrimination, the lack of social networks, and unfamiliarity with the local education system. For example, Suzie, a Malaysian-Chinese parent, explained that she relied on private tutoring to give her son the educational support that she and her partner could not provide:

because we didn't grow up here, and we don't know the education system here... They go to school without text books and for us we feel like we don't know what they are teaching. Also we don't know how to guide them as well. So by sending them to tutoring centre, it just makes sure that someone else will guide them.

Having experienced discrimination and a career downgrade following migration, Suzie emphasised education as a means for protecting her children against racism. She was 'sure' her children would face discrimination, despite having been brought up in Australia. She said that though they might consider themselves 'white', they would never be accepted as such by the mainstream population. Educational qualifications were crucial for social mobility in such a context.

In contrast to the importance they placed on education, many Asian-Australian parent respondents were dissatisfied with the perceived lack of rigour in Australian schools. As Cecilia, a Chinese-Australian parent, said, 'school is too relaxed', and did not 'push' students enough. This is why she sent her son to tutoring. She hoped that as her son entered senior high school, he would start to 'feel that pressure', explaining, 'I think there should be a little bit of stress, otherwise he won't work hard'. Lien agreed that her high school-aged children 'should be more stressed' because that would indicate they were taking their studies seriously.

This is reminiscent of Sriprakash et al's (2015) study of Chinese-Australians' use of private tutoring, which argues that while tutoring is usually perceived as a 'cultural' practice associated with certain migrant groups, it should also be seen in pedagogical terms. Chinese migrants' unfamiliarity and dissatisfaction with the pedagogically progressive approach of Australian primary schooling - which downplays formal assessment and ranking - leads them to seek more explicit and 'visible' forms of instruction through private tutoring. 
The pedagogical approach of selective high schools, in which formal assessment, examinations and ranking play a much more important role, also creates an intense focus on academic outcomes. In contrast to the Asian-Australian parents who questioned the work ethic within schools, the senior high school students I interviewed, along with recent high school graduates, described being engulfed in a culture of aspiration, competition and stress. This culture seemed as much a product of the particular culture of the school as a reflection of 'Asian' culture. For example, Wei, a recent child migrant from China in her final year of high school, emphasised throughout her interview her desire to 'get ahead' and 'stay on top'. But when I asked her what her final exam goal was, she said she actually did not need to achieve a top ranking to gain entry into her chosen university course. She admitted,

I just constantly want to try my best, but I don't know if it's worth it. Like the effort that I'm putting in right now, what am I aiming for? Because I'm in an environment where everybody tries their hardest, so that I just try my hardest.

Similarly, Winnie explained that her work ethic was largely a product of attending an elite selective school, rather than something innate. She stated that she was not naturally an 'intellectual' person, and if she had attended a comprehensive high school, she would probably not have ended up in university, but probably would have 'partied more', eventually studying 'make up', 'because that's what I'm really interested in'.

The micro practices of schools can fuel the competitive behaviour of students and parents. For example, Suzie described how her children's primary school had recently started publishing the names of the children who gained entry into a selective school. She said this created much more pressure among some parents. She recounted one incident where a Korean-Australian parent had deliberately applied for a less prestigious selective school, to maximise her child's chances of being included on the list of successful applicants. In fact however, the child had already been enrolled into a private high school for the following year.

While this incident may confirm the stereotype of the competitive Asian 'tiger parent' in the eyes of some, such behaviour would not have occurred if the school had not introduced its policy of publicly honouring some of its students. As Campbell et al (2009, p. 106) write, the selective system offers a highly valued 'commodity' under conditions of great unsatisfied demand, creating 'perfect conditions for the encouragement of competitive behaviour by parents'. However, within these environments, competitiveness becomes racialised as 'Asian', even by Asian-Australians themselves. 


\section{A hyper-racialised environment}

Ultimately, everyday multiculturalism is about making cultural difference normal and unremarkable. However, in elite selective schools, the demographic makeup of the student population creates a hyper-racialised environment in which people are eternally defined by their ethnicity. Rather than becoming unremarkable, cultural difference is hyper-visible and often the primary means by which people identify themselves and others. Such schools are where students and parents 'make each other racial' (Olsen, 1997; see also Pollock, 2004).

Robert gave the banal example of lunchtime soccer games, in which teams were organised along ethnic lines: 'checkerboards versus the Asians', or in other words, 'the Indians and the white people versus the Asians'. He asserted, 'it's not racist... it's just like a visual quick identification system'. So if someone refers to 'that curry kid over there with the curly hair, everyone knows it's the Indian guy'. When I asked him whether anyone was offended by such classifications, Robert replied, 'the kid might be, but he doesn't hear it'. He quickly added that he had Indian friends who also called each other 'curry', so 'it's fine'.

More generally, respondents discussed students' aptitudes, abilities and preferences in racialised terms. Even subjects were racialised. For example, Robert explained that there was a combination of senior high school subjects known as the 'Asian five', which emphasised sciences and mathematics. Even though he himself - an Anglo-Australian - was completing four out of these five subjects, the combination was seen as 'Asian'.

Racialised labels are not necessarily racist. Often they reflect the playful and ironic categorising, banter and jovial mocking that typifies youth culture. As Winkler Reid (2015, p. 24) notes, among young people, practices of classification of ethnicity are commonplace and banal, and 'embedded in the dynamic flow of social action; in one moment indicating reification of ethnic or racial differences, and in the next irony and ambiguity'. Emphasising ethnic difference - and even using derogatory terms - can be a source of fun: using irony and sarcasm can have the subversive effect of creating conviviality rather than antagonism (Winkler Reid, 2015, p. 35).

At other times, racialised categories are more damaging. Robert complained about the stereotype that whites were 'hopeless at maths', which sometimes severely damaged students' self-confidence in the subject. True to form, Wei, a Chinese-Australian student, confided that her Asian-Australian peers did 'look down' on people who they saw as nonhigh achievers, in the context of recounting an experience she and her friends had playing 
'mathematical card games' with Anglo-Australians. Conversely however, Robert spoke derisively of 'thick' Asian-Australian students who had no 'natural' intelligence, which was evident in their failure to grasp 'logic-based games' such as Cluedo.

In such cases, the hyper-racialised environment of selective schools created attitudes that were outright racist, or bordered on it. The racialised resentment among some parent respondents sometimes erupted into blatantly hostile racial stereotyping (and there may have been more of this if the interviewer had been white). For example, Robert's father, who had been at the periphery of our conversation, intervened at one point with this statement:

they come to this country and it's all about taking more and getting away with more... I know a lot of Asian people spend their weekend with their accountant - all the little loopholes to get away with more... but your average Skippy, white person, pommy, whatever you want to call it - we're just pretty relaxed and yeah if we have to pay tax, we pay tax, we're not pick, pick, picking try to get away with more.

\section{Cosmopolitan Kids: A counter-trend}

Among my Anglo-Australian interviewees, two stood out because of their cosmopolitan outlook. Simone's response to attending an Asian-dominated school was to embrace all things Asian. She told me all her friends were Asian but she 'never felt that much like an outsider'. She was the only Anglo-Australian in her friendship group, which wasn't unnoticed, but 'it was never an issue'. She explained that although the Anglo students tended to 'stick together' at her school, she did not join them, although she was on friendly terms with them. Simone was a fluent Mandarin speaker, having studied the language all through high school, and explained that her career goal was to become Australia's ambassador to China. 'That's not a lofty goal at all!', she laughed.

Another Anglo-Australian student, Thomas, who had grown up in a very White monocultural area of Sydney, said that at the beginning of high school, he and his family were confronted at the sight of so many Asian students. However, it soon became normal for him, and like Simone, he chose to study Chinese, and at the time of interview, Thomas had finished his university degree (in which he had continued his Chinese language study) and was about to move to China, with his Chinese girlfriend, to begin his career there.

Both Simone and Thomas had developed an intimate understanding of the experiences of Asian migrants in Australia because of their school years, enabling them to better 
understand the education cultures of both Asian- and Anglo-Australians. For example, although Simone had never attended tutoring, and would 'not encourage the culture of tutoring that goes on', she believed it was unfair to cast tutoring as 'cheating', because students attending tutoring 'work exceptionally hard' and deserved their success. She saw the culture of tutoring in terms of the circumstances of migrant families, who just 'want to make the most out of the opportunity that's given to them here in Australia'.

Simone and Thomas' experiences indicate that for some Anglo-Australian students, being an ethnic minority at school enables a genuine development of cross-cultural understanding, and a broadening of one's own expectations, desires and goals. These students are able to realise the benefits of everyday multiculturalism during their schooling.

\section{Conclusion}

Everyday multiculturalism is about people negotiating across cultural borders in order to share a common space, whether this is a neighbourhood, workplace, school, or other local setting. This paper has shown that the structure of the selective school system creates an unusual everyday multiculturalism, characterised by a hyper-racialised environment in which students and their families differentiate themselves from others on the basis of ethnicity. While this does not necessarily lead to ethnic tension among students at an everyday level, there is evidence of racialised resentment among Anglo-Australian parents feeling excluded from the selective system, and marginalised within it.

At the more systemic level, selective schools and classes are segregated from mainstream schools and from their local communities. Their demographic composition does not reflect the cultural or social diversity of Australian society, and nor do they reflect the demographic profile of the local areas in which they are located. Rarely do selective students live locally. Some travel hours each day to and from school. While the local public school can be an important site of everyday multiculturalism for children and their families, selective schools rarely function as local schools, depriving their local areas of this potential 'micropublic'. Therefore as Australia's education system becomes increasingly segmented by policies encouraging choice and competition, our school communities are less and less likely to include the full range of cultural and social diversity found in our society. This is particularly the case in more socially-advantaged or middle-class environments, where 
families are more likely to exercise school choice, and therefore not send their children to the local comprehensive public school.

While some students in selective schools adopt more open and cosmopolitan outlooks, leaving their comfort zones to immerse themselves in new cultural settings, this occurs against a backdrop of the hyper-racialised environment they inhabit every day. The ethnically unbalanced profile of selective schools is a product of Australia's elitist migration and education policies, working together to create an environment of increasing competition and anxiety for both Anglo-Australians, who fear that their children are being denied opportunities they traditionally had, and for Asian-Australians, who, acutely aware of the challenges and opportunities associated with their migrant status, place additional pressure on their children to excel in the one arena that they believe will safeguard their future. These are not optimal conditions for fostering healthy intercultural relations. 


\section{References}

ACARA (Australian Curriculum, Assessment and Reporting Authority) (2016). MySchool, Retrieved from http://www.myschool.edu.au.

ACARA (2017). What does the ICSEA value mean? Retrieved from https://acaraweb.blob.core.windows.net/resources/About_icsea_2014.pdf

Amin, A. (2002). Ethnicity and the Multicultural City: Living with diversity. Environment and Planning A, 34(6), 959-80.

Archer, L. \& Francis, B. (2007). Understanding minority ethnic achievement: Debating race, gender, class and 'success'. London: Routledge.

Aris, S. (2017). Indian Tigers: What High School Selection by Parents Pursing Academic Performance Reveals about Class, Culture and Migration, Journal of Ethnic and Migration Studies, forthcoming.

Armitage, C. (2016, June 18). 'How difficult is it to get into Sydney's best-performing high schools?' The Sydney Morning Herald. Retrieved from http://www.smh.com.au/national/education/how-difficult-is-it-to-get-into-sydneysbestperforming-high-schools-20160618-gpm8i4.html.

Booth, A. L., Leigh, A. \& Varganova, E. (2012). Does ethnic discrimination vary across minority groups? Evidence from a field experiment. Oxford Bulletin of Economics and Statistics, 74(4), 547-73.

Broinowski, A. (2015, January 24). Testing times: selective schools and tiger parents, Good Weekend. Retrieved from http://www.smh.com.au/good-weekend/testing-times-selective$\underline{\text { schools-and-tiger-parents-20150108-12kecw.html }}$

Campbell, C., Proctor, H. \& Sherrington, G. (2009). School Choice: How parents negotiate the new school market in Australia. Sydney: Allen \& Unwin. 
DIAC (Department of Immigration and Citizenship) (2014a). Community Information Summary: China-born. Accessed 21 October 2015. Retrieved from https://www.dss.gov.au/sites/default/files/documents/02_2014/china.pdf.

DIAC (Department of Immigration and Citizenship) (2014b). Community Information Summary: Republic of South Korea-born. Accessed 21 October 2015. Retrieved from https://www.dss.gov.au/sites/default/files/documents/02_2014/korea.pdf.

DIAC (Department of Immigration and Citizenship) (2014c). Community Information Summary: India-born. Accessed 21 October 2015. Retrieved from https://www.dss.gov.au/sites/default/files/documents/02_2014/india.pdf.

Forsey, M. (2010). Publicly minded, privately focused: Western Australian teachers and school choice. Teaching and Teacher Education, 26(1), 53-60.

Harris, A. (2013). Young People and Everyday Multiculturalism. London: Routledge.

Ho, C. (2011). Respecting the Presence of Others: School Micropublics and Everyday Multiculturalism. Journal of Intercultural Studies, 32(6), 603-619.

Ho, C. (2015). 'People like us': School choice, multiculturalism and segregation in Sydney. Australian Review of Public Affairs, August.

Ho, C. (2017a). The new meritocracy or over-schooled robots? Public attitudes on AsianAustralian education cultures. Journal of Ethnic and Migration Studies, forthcoming.

Ho, C. (2017b). Selective schools increasingly cater to the most advantaged students, The Conversation, 9 March, Retrieved from https://theconversation.com/selective-schoolsincreasingly-cater-to-the-most-advantaged-students-74151

Ho, C., Vincent, E. \& Butler, R. (2015). Everyday and Cosmo-Multiculturalisms: Doing Diversity in Gentrifying School Communities. Journal of Intercultural Studies, 36(6), 658675. 
Hollingworth, S. \& Mansaray, A. (2012). Conviviality under the cosmopolitan canopy? Social mixing and friendships in an urban secondary school. Sociological Research Online 17(3), 2.

Lareau, A. (2003). Unequal Childhoods: Class, race and family life. Berkeley: University of California Press.

Lee, J. \& Zhou, M. (2015). The Asian American Achievement Paradox. New York: Russell Sage Foundation.

Lee, J. \& Zhou, M. (2017). Why Class Matters Less for Asian American Academic Achievement. Journal of Ethnic and Migration Studies, forthcoming.

Louie, V. S. (2004). Compelled to Excel: Immigration, education, and opportunity among Chinese Americans. Stanford: Stanford University Press.

Martin, P. (2009, December 8). China now biggest source of migrants, The Sydney Morning Herald, Retrieved from http://www.smh.com.au/national/china-now-biggest-source-of$\underline{\text { migrants-20091207-kffd.html. }}$

Milburn, C. (2011, October 17). Fears over 'white flight' from selective schools, The Sydney Morning Herald. Retrieved from http://www.smh.com.au/national/education/fears-overwhite-flight-from-selective-schools-20111016-11ro2.html

Neal, S. \& Vincent, C. (2013). Multiculture, middle class competencies and friendship practices in super-diverse geographies. Social \& Cultural Geography 14(8), 909-29.

Neill, R. (2016, November 5). Hyper-racialised selective schools broaden ethnic divide, The Australian, Retrieved from http://www.theaustralian.com.au/news/inquirer/hyperracialisedselective-schools-broaden-the-ethnic-divide/newsstory/c7a89e9506b5b82d3ef7c001004a1681. 
Noble, G. (2009). Everyday Cosmopolitanism and the Labour of Intercultural Community. In A. Wise \& S. Velayutham (Eds.), Everyday Multiculturalism, (pp. 46-65). London: Palgrave Macmillan.

Noble, G., et al. (1999). Youth, ethnicity and the mapping of identities: Strategic essentialism and strategic hybridity among male Arabic-speaking youth in South-Western Sydney.

Communal/Plural, 7(1), 29-44.

NSW Government (2016a). 'Secondary schools - selective high schools', Retrieved from http://www.schools.nsw.edu.au/gotoschool/types/selectiveschools.php Accessed: 13 October 2016.

NSW Government (2016b). 'Primary schools with opportunity classes', Retrieved from http://www.schools.nsw.edu.au/gotoschool/types/primarywithoc.php Accessed: 13 October 2016.

Olsen, L. (1997). Made in America: Immigrant Students in Our Public Schools. New York: The New Press.

Omi, M. \& Winant, H. (1994). Racial Formation in the United States: From the 1960s to the 1990s. $2^{\text {nd }}$ ed. New York: Routledge.

Patty, A. (2010, September 13). Are migrant parents pushing their kids too hard at school? The Sydney Morning Herald. Retrieved from http://www.smh.com.au/it-pro/are-migrantparents-pushing-their-kids-too-hard-at-school-20100912-156t8.html

Pollock, M. (2004). Race Bending: 'Mixed' youth practicing strategic racialization in California. Anthropology and Education Quarterly 35(1), 30-52.

Poyatos Matas, C. \& Bridges, S. (2008). Multicultural capital in middle schooling, The International Journal of Diversity in Organisations, Communities and Nations, 8(2), 1-17.

Poyatos Matas, C. \& Bridges, S. (2009). Framing multicultural capital to understand multicultural education in practice, The International Journal of Learning, 16(10), 379-395. 
Proctor, H. \& Sriprakash, A. (2017). Race and Legitimacy: Historical Formations of Academically Selective Schooling in Australia, Journal of Ethnic and Migration Studies, forthcoming.

Reay, D. (2004). Education and cultural capital: The implications of changing trends in education policies. Cultural Trends, 13(2), 73-86.

Reay, D., Hollingworth, S., Williams, K., Crozier, G., Jamieson, F., James, D. \& Beedell, P. (2007). 'A Darker Shade of Pale?' Whiteness, the Middle Classes and Multi-Ethnic Inner City Schooling. Sociology, 41(6), 1041-60.

SBS [Special Broadcasting Service] (2015, January 25). Indians now 20 per cent of migrants to Australia, SBS News, http://www.sbs.com.au/news/article/2015/06/17/indians-now-20cent-migrants-australia?cx_navSource=related-side-cx\#cxrecs_s.

Spivak, G. C. (1987). In Other Worlds: Essays in Cultural Politics. New York: Routledge.

Sriprakash, A., Proctor, H. \& Hu, B. (2015). Visible pedagogic work: parenting, private tutoring and educational advantage in Australia. Discourse: Studies in the Cultural Politics of Education, 37(3), 426-421.

Thomas, M. (2011). Multicultural Girlhood: Racism, Sexuality, and the Conflicted Spaces of American Education. Philadelphia: Temple University Press.

Vincent, C. \& Ball, J. S. (2007). 'Making Up' the Middle-Class Child: Families, Activities and Class Dispositions. Sociology, 41(6), 1061-77.

Watkins, M. (2017). 'We are All Asian Here': Multiculturalism, Selective Schooling and Responses to Asian Success. Journal of Ethnic and Migration Studies, forthcoming.

Watkins, M., \& Noble, G. (2013). Disposed to Learn: Schooling, ethnicity and the scholarly habitus. London: Bloomsbury Academic. 
Willoughby, L. (2007). Interethnic relations: A case study of senior students at an Australian high school. International Education Journal, 8(1), 254-264.

Windle, J. (2015). Making Sense of School Choice: Politics, Policies and Practice under Conditions of Cultural Diversity. New York: Palgrave Macmillan.

Winkler Reid, S. (2015). Making Fun out of Difference: Ethnicity-Race and Humour in a London School. Ethnos, 80(1), 23-44.

Wise, A. \& Velayutham, S. (2009). Introduction. In A. Wise \& S. Velayutham (Eds). Everyday Multiculturalism (pp. 1-17). London: Palgrave Macmillan. 